\title{
Allelic polymorphism of glucocorticoid receptor NR3C1 (GR): from molecular biology to clinical implications
}

\author{
M. A. Orlovsky \\ O. O. Bogomoletz Institute of Physiology, NAS of Ukraine \\ Akademika Bogomoltsa Str., 4, Kyiv, Ukraine, 01004 \\ dr.orlovsky@gmail.com
}

\begin{abstract}
Polymorphism of stress-related genes is a key factor determining difference in the stress reactivity and resistance among humans. Glucocorticoid receptors are important actors of stress responses. This review is focused on the molecular biology and clinical implications of glucocorticoid receptor gene polymorphism.
\end{abstract}

Keywords: glucocorticoid receptors, allelic polymorphism, SNP, NR3C1, GR, stress-induced pathology.

The diseases of civilization (arterial hypertension, atherosclerosis, sugar diabetes, immunodeficiency, autoimmune pathology, bipolar disorders and depression) are of significant economic and humanitarian damage to modern humankind. They are based on the systemic down-regulation, occurring as a response to the allostatic load, distress and disadaptation. Glucocorticoid hormones as stress effectors and agents of the adaptation to stress take instant part in the regulation of metabolism, homeostasis, immune reactions, endocrine state and psychiatric processes, which influences the mood, memory, and general psychological activity. Among genes-stress regulators, the genes of glucocorticoid receptors should be paid special attention. The current review presents the analysis of the genetics and molecular biology of the receptors of glucocorticoid hormones (NR3C1), the spectrum of activation effects which includes the range from epigenetic modifications of the genome to the impact on psychiatric processes.

Gene structure and expression regulation. The glucocorticoid hormone receptor gene $\mathrm{NR} 3 \mathrm{Cl}$ (nuclear receptor subfamily 3 , group $\mathrm{C}$, class 1 ) is present in the

(C) Institute of Molecular Biology and Genetics, NAS of Ukraine, 2012 human genome in the only copy, located in the locus 5q31.3 (long arm of chromosome 5, site 3, band 1, subband 3). The length of the gene is 157581 base pairs, it contains nine exons, coding for the sequences of 777 aminoacid residues [2]. The gene structure is presented in Fig. 1 and 2.

The expression of $\mathrm{NR} 3 \mathrm{Cl}$ gene is under the control of several alternative first exons (according to different data, from seven to nine), preceding $\mathrm{CpG}$-rich sequence (promotor region) [3, 4]. Seven tissue-specific promotors, promoting different mechanisms of genetic control over the gene expression in organs and tissues, are localized in introns between these alternative exons. The methylation of alternative exons and promotors is the epigenetic mechanism of the regulation of gene activity [4]. The activity of different promotors is likely to have impact on the choice of a specific mechanism of splicing, leading to the formation of some isoforms of receptors. The genetic polymorphism of the regulatory sites is known for its association with the development of depressive disorders [5].

Splicing and translation. Receptor isoforms. The formation of eight splice-variants, coding for four main isoforms of the receptor - GR- $\alpha$, GR- $\beta$, GR- $\gamma$, as well as little-studied isoform GR-P is possible after the 


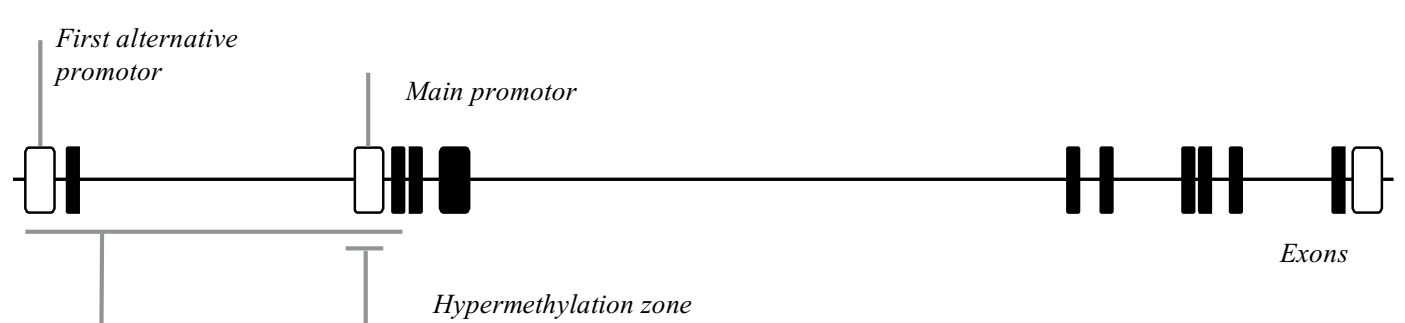

Region of alternative promotors and first exons

$\begin{array}{llll}\text { Fig. } \quad 1 & N R 3 C 1 & \text { gene } \\ \text { structure } & \end{array}$

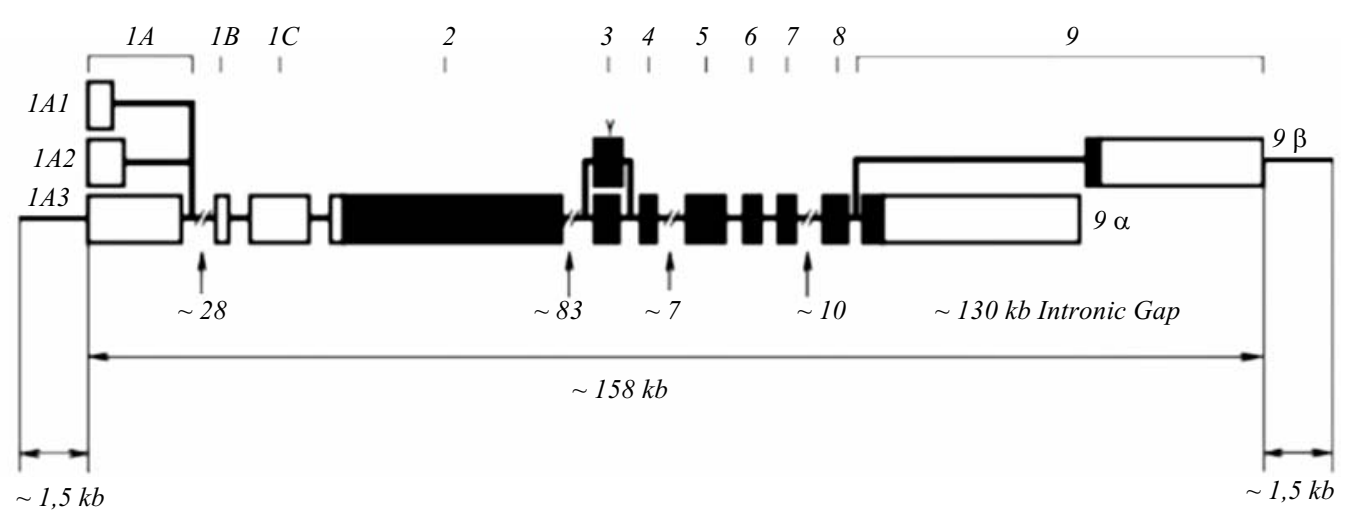

Fig. 2 Non-translational regions (white blocks) and the intron-exon structure of $\mathrm{NR} 3 \mathrm{Cl}$ gene (according to [31])

alternative splicing of pro-mRNA, read from the sequence of $N R 3 C 1$ gene (Table 1). Besides, the shift of the reading frame in the process of the initiation of translation leads to a number of additional isoforms of the receptor GR- $\alpha$ (GR- $\alpha \mathrm{A}, \mathrm{GR}-\alpha \mathrm{B}, \mathrm{GR}-\alpha \mathrm{C}$ and GR- $\alpha \mathrm{D}$; Table 2). This mechanism of the alternative initiation of translation is typical for the synthesis of protooncogenes, the transcription regulators, kinases and growth factors in eukaryotes [7]; it allows increasing the number of protein products of the same gene, thus enlarging the range of its physiological functions and the number of tissue-specific variants of the response [6].

The receptor isoforms are remarkable for C-terminal site which influences the mechanisms of cytoplasmicnuclear traffic and the activation of target genes [6]. The most wide-spread form of the receptor is GR- $\alpha$ [6], the aminoacid sequence of which is presented in Fig. 1. $\alpha$-Isoform is presented by a number of shorter subisoforms with some absent aminoacids at C-terminal end (Table 2) which does not influence the binding to the hormone, but modifies the processes of translocation of the activated receptors into the nucleus [6].

The main distinction of the less prevailing variant, GR- $\beta$, the level of expression of which is about $1 \%$ of GR- $\alpha$ one [8], is the absence of specific glucocor- ticoid-binding domain [9]. $\beta$-isoform is predominantly localized in the nucleus and is likely to serve as a dominantly negative regulator of GR- $\alpha$ and MR, it is also capable of competing with the latter for the sites of promotors as well as forming heterodimers $[9,8]$. Thus, lower level of sensitivity of neutrophils to glucocorticoid-mediated apoptosis, compared to T-lymphocytes, is likely to be conditioned by the increased expression of GR- $\beta$ in these cells. At the same time some authors doubt the capability of GR- $\beta$ to inhibit the effects of GR- $\alpha$ in the physiological and pathological conditions, as due to the low level of GR- $\beta$ basic expression, at least 500-fold increase in its synthesis is required to obtain a significant effect [8]. It was established that GR- $\beta$ inhibits only the transactivational effects of GR- $\alpha$, not affecting the induced transrepression [8]. In addition, the effect of GR- $\beta$ on more high-affine MR is also possible in the physiological conditions [8]. It should be noted that the isoform GR- $\beta$ is not observed in rats as they do not have the corresponding site of the active splicing in $\mathrm{NR} 3 \mathrm{Cl}$ gene [11]. The physiological significance of other isoforms of the receptor, in particular, GR- $\gamma$ and GR-P, is yet to be studied in detail.

The isoform GR- $\gamma$ was described by Rivers et al. [12] in 1999. It contains an additional arginine in the 
Human gene NR3C1 mRNA spilce variant

\begin{tabular}{|c|c|c|c|}
\hline $\begin{array}{c}\text { Identifier in the catalog } \\
\text { NCBI RefSeq }\end{array}$ & Characteristics & Resulting protein & Reference \\
\hline NM_000176.2 & $\begin{array}{l}\text { Main transcript, coding the most common } \\
\text { receptor isoform }\end{array}$ & $\begin{array}{l}\text { GR- } \alpha \text { isoforms, obtained after alternative variants of } \\
\text { mRNA translation initiation: } \\
\text { GR-A, GR-B, GR-C, GR-D and their subtypes }\end{array}$ & {$[6]$} \\
\hline \multicolumn{4}{|l|}{ NM_001204258.1 } \\
\hline \multicolumn{4}{|l|}{ NM_001204259.1 } \\
\hline \multicolumn{4}{|l|}{ NM_001204260.1 } \\
\hline \multicolumn{4}{|l|}{ NM_001204261.1 } \\
\hline \multicolumn{4}{|l|}{ NM_001204262.1 } \\
\hline \multicolumn{4}{|l|}{ NM_001204263.1 } \\
\hline \multicolumn{4}{|l|}{ NM_001204264.1 } \\
\hline NM_001018074.1 & $\begin{array}{l}\text { Variants with alternative 5'-non-coding } \\
\text { sequences }\end{array}$ & & \\
\hline \multicolumn{4}{|l|}{ NM_001018075.1 } \\
\hline \multicolumn{4}{|l|}{ NM_001018076.1 } \\
\hline \multicolumn{4}{|l|}{ NM_001018077.1 } \\
\hline NM_001020825.1 & $\begin{array}{l}\text { Formed due to alternative site of } \\
\text { splice-acceptors in 3'-terminal exon }\end{array}$ & GR- $\beta$ & [9] \\
\hline NM_001024094.1 & $\begin{array}{l}\text { Formed due to alternative splicing in the } \\
\text { site of one of the encoding exons }\end{array}$ & GR- $\gamma$ & [12] \\
\hline NM_001204265.1 & Variant without two exons at 3'-end & GR-P & {$[40,41]$} \\
\hline
\end{tabular}

structure of DNA-binding domain, occurring as a result of alternative splicing of the intron between the $3^{\text {rd }}$ and $4^{\text {th }}$ exons. This modification is known to induce the reduction in the transcriptional activity of the receptor by $48 \%$ [13]. GR- $\gamma$ is highly expressed in different tissues, its share is in the range of $3.8-8.7 \%$ in the total population of GR receptors [12].

Receptor structure. The receptor consists of four domains, three of which are presented by highly conservative sequences, present in other proteins (Table 3 , Fig. 3). The effect of GR is achieved via dimers, which may exist in the form of homo- and heterodimers with MR. Homo- and heterodimers induce different subgroups of genes, providing fine regulation depending on changing levels of hormones in stress conditions $[14,15]$. In this respect high significance is attributed to the fact that the character and magnitude of GR/MRmediated responses is determined not only by binding receptors to ligands, but also by the presence of nonsteroid coregulators, coactivators and corepressors [15]. The dimer configuration of a GR molecule differs from that of the receptors of other steroid hormones and contains an additional intermolecular $\beta$-layer [16].

Receptor activation. Under basic cellular conditions the receptor exists in the composition of a multiprotein complex with one GR molecule and heat shock proteins - two hsp90 molecules, one hsp70, one hsp56 and immunomodulin [8].

The hormone binding to the receptor leads to a number of events, including the dissociation of heat shock proteins, immunomodulin and phosphorylation of GR, inducing the transportation of the 
Table 2

Human GR receptor isoforms (gene NR3C1)

\begin{tabular}{|c|c|c|}
\hline Isoform & Structure & Localization and function \\
\hline $\begin{array}{l}\text { GR- } \alpha(\alpha-A, \\
\quad \text { GR-A) }\end{array}$ & $\begin{array}{l}\text { Main receptor isoform, containing DNA- and } \\
\text { hormone-binding domains }\end{array}$ & $\begin{array}{l}\text { Located in the cytoplasm; is transported into the nucleus after } \\
\text { ligand-binding, where it operates. Isoforms differ in the } \\
\text { mechanisms of transportation into the nucleus [6] }\end{array}$ \\
\hline GR- $\alpha B$ & Terminated at codon $571-573$ & $\begin{array}{l}\text { Short receptor isoforms, different in the mechanisms of } \\
\text { transportation into the nucleus }[6]\end{array}$ \\
\hline GR- $\alpha \mathrm{C} 1$ & Terminated at codon $748-750$ & \\
\hline GR- $\alpha \mathrm{C} 2$ & Terminated at codon $760-762$ & \\
\hline GR- $\alpha \mathrm{C} 3$ & Terminated at codon $784-786$ & \\
\hline GR- $\alpha \mathrm{D} 1$ & Terminated at codon $1438-1440$ & \\
\hline GR- $\alpha \mathrm{D} 2$ & Terminated at codon $1483-1485$ & \\
\hline GR- $\alpha$ D3 & Terminated at codon $1498-1500$ & \\
\hline GR- $\beta$ & $\begin{array}{l}\text { Shorter isoform, compared to GR- } \alpha \text {, with prominent } \\
\text { C-terminal part, non-containing the hormone-binding } \\
\text { domain [9]. Not observed in rats [11]. }\end{array}$ & $\begin{array}{c}\text { Predominantly localized in the nucleus, a dominantly-negative } \\
\text { regulator of GR- activity [9]. }\end{array}$ \\
\hline GR- $\gamma$ & $\begin{array}{l}\text { DNA-binding domain contains the additional amino } \\
\text { acid (arginine) }\end{array}$ & Lower affinity to GRE compared to GR- $\alpha$ [12] \\
\hline GR-P & $\begin{array}{c}\text { Shorter C-terminal area, not observed in other } \\
\text { isoforms }\end{array}$ & $\begin{array}{c}\text { Unknown function. Highly expressed in glucocorticoid-resistant } \\
\text { cell lines, may serve as a modulator of susceptibility to } \\
\text { glucocorticoids }[40,41]\end{array}$ \\
\hline \multicolumn{3}{|c|}{$\begin{array}{l}\text { Table } 3 \\
\text { GR- } \alpha \text { A proteins' domains }\end{array}$} \\
\hline Localization & Domain & Function \\
\hline $1-420$ & Transactivational & Interaction with transcription factors \\
\hline $419-486$ & DNA-binding by "zinc fingers" type & $\begin{array}{l}\text { Interaction with GRE-sequence of DNA and modulation } \\
\text { of transcription initiation frequency }\end{array}$ \\
\hline $487-527$ & Hinged & Molecular structure motility \\
\hline $528-777$ & Ligand-binding & Hormone-binding, translocation into the nucleus \\
\hline
\end{tabular}

hormonereceptor complex in the nucleus [8]. The half-life of the hormone-receptor complex for GR is 5 $\min$ (compared to $45 \mathrm{~min}$ for MR) [14]; $\mathrm{K}_{\mathrm{D}}$ dissociation constant is $\approx 0.5 \mathrm{nM}[8]$.

The level of receptor-activating glucocorticoid hormones in blood is susceptible to pulse fluctuations in the course of 24 hours. The average duration of one secretion pulse for rats is approximately one hour. In the evening the secretion peaks are more frequent, they follow each other almost without any intervals and have high amplitude; in the morning their amplitude is decreased and they are divided by intervals of half an hour or an hour $[14,17]$. In the blood the glucocorticoids interact with corticosteroid-binding proteins (CBP) [8]; their penetration via hematoencephalic barrier is regulated by P-glycoprotein mdr1 A (multiple drug resistance) [18].

The peak concentrations of glucocorticoids in blood induce the activation and translocation of GR molecules into the nucleus as early as after $30 \mathrm{~min}$ (in the basic conditions GR receptors in the nucleus are practically not present) $[14,19]$. Then their level 


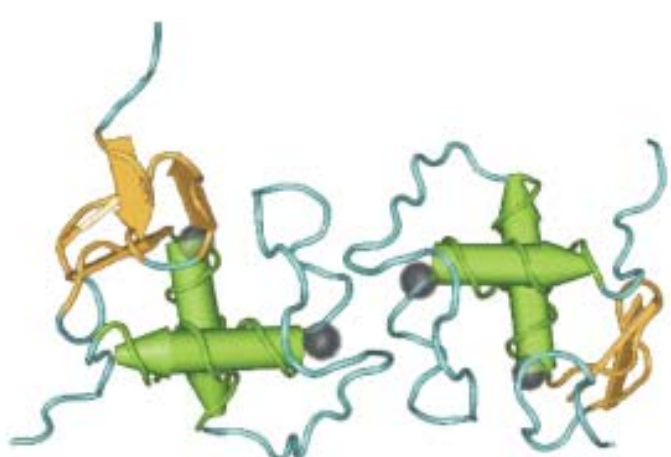

Fig. 3 DNA-binding domain of the glucocorticoid receptor

diminishes to the initial values rather fast (in the course of $90 \mathrm{~min}$ ) [14, 19]. Therefore, the total duration of the activation cycle of receptors, their translocation and elimination from the nucleus is $120 \mathrm{~min}$. The elimination of receptors from the nucleus occurs due to their proteasome degradation in the nucleus; it is blocked by the inhibitors of 26S-subunit of the proteasome [14]. The cytoplasmic concentration of receptors in the course of this cycle does not decrease considerably which testifies to only a small amount of receptors, passing in each recruiting cycle [14].

Post-translational modification. Currently 14 different variants of post-translational modification are described for human GR molecule, including phosphorylation, sumoylation and ubiquitination (Table 4). The phosphorylation and dephosphorylation of GR are of considerable impact on the function of the receptor, its intracellular traffic and affinity to ligands [20]. In a free state the receptor is phosphorylated (sites Tre171 and Ser246 in GR of rats [21]), however, the binding of the hormone (not the antagonists) leads to its further phosphorylation, which is likely required for the physiological activity [22]. This phosphorylation seems to occur in sites Ser 203 and Ser211 with the participation of cyclin-dependent kinases [20,22]. These phosphorylation sites are related to the regulation of the traffic of the activated receptor into various cellular compartments: GR-Ser211P is found in the nucleus, while GRSer203-P and twice phosphorylated GR-Ser 203/Ser211-P are present only in the cytosol [22]. The phosphorylation of Ser226 site with the involvement of JNK and MAPK leads to the accelerated withdrawal of the receptor from the nucleus, inhibiting the transcription of glucocorticoid-dependent genes [23, 21]. The replacement of serine by alanine (Ser266A1a) in this locus induces the loss of sensitivity of GR receptor to the effect of JNK [23]. The activation of JNK occurs with the participation of cytokines, lipopolysaccharides and osmotic stimuli [23] and the phosphorylation by Ser226 residue may be the mechanism of contraregulation of the systemic immune and stress response.

Besides the phosphorylation, GR protein is affected by the recently discovered process of sumoylation, conjugated with specific small ubiquitin-related modifier (SUMO-1) [24]. The process is catalyzed by E3-ligases, which are different from the ligases, participating in the ubiquitination. The sumoylation modifies the traffic and the activity of a number of proteins. GRs may be sumoylated in three loci, related to the transactivational domain (Lys277 and Lys293) and the ligand-binding domain in the $\mathrm{C}$-terminal region (Lys703) which leads to the modification of the transcriptional activity of the receptor, and the observed effect is promotor-dependent [24]. The sites of the transactivational domain are more susceptible to this type of modification compared to those of the ligandbinding domain. The glucocorticoid hormones are likely to stimulate the sumoylation of the receptor via its translocation into the nucleus with the corresponding E3-ligase (Ubc9) [24].

The glucocorticoid receptor may function in two modes: as a transcription factor, binding to the glucocorticoid-responsive elements of DNA (GRE) and as a regulator of the activity of other transcriptional factors. In 2009 it was established that different GR-binding nucleotide sequences of DNA serve as cofactors in the activity of the receptor, specifically and differentially changing its conformation and thus affecting the expression of some genes [25].

Receptor degradation. Similar to the majority of other nuclear receptors, GR is a substrate of the ubiquitin-dependent proteasome degradation [14, 26, 27]. CHIP complexes [26] and the protein Mdm2 (E3-ligase) participate in the processes of the proteasome degradation of receptors [28].

The recruiting of various subunits of the proteasome and E3-ligases into the promotor region during the activation of the steroid hormone receptors is a required condition for their effect, and the blockade of proteasome proteolysis may cause the association of the receptors and chromatin [26]. On the other hand, the 
Table4

Postranslational modification $G R-\alpha A$ sites

\begin{tabular}{|c|c|c|c|c|c|c|}
\hline № & Position & Aminoacid & Modification & Kinase & Significance & Reference \\
\hline 1 & 8 & Threonine & Phosphorylation & - & - & - \\
\hline 2,4 & 45,134 & Serine & Phosphorylation & - & - & - \\
\hline 3,5 & 133,141 & Serine & Phosphorylation & - & - & {$[20,42]$} \\
\hline 7,8 & 203,211 & Serine & Phosphorylation & $\mathrm{Cdk}$ & $\begin{array}{l}\text { Activates the receptor after } \\
\text { hormone-binding }\end{array}$ & {$[22]$} \\
\hline 9 & 226 & Serine & Phosphorylation & $\begin{array}{l}\text { ERK2, MAPK-8, } \\
\text { JNK }\end{array}$ & Decreases receptor activity & {$[21,23]$} \\
\hline 10 & 234,267 & Serine & Phosphorylation & - & - & - \\
\hline 11 & 277,293 & Lysine & Sumoylation & Ubc9 (Е3-лигаза) & - & {$[24]$} \\
\hline 12 & 419 & Lysine & $\begin{array}{l}\text { Ubiquitination in } \\
\text { DNA-binding domain }\end{array}$ & $\begin{array}{l}\text { CHIP, Mdm2 } \\
\text { (Е3-лигаза) }\end{array}$ & Possible PEST-marker of degradation & {$[26-28]$} \\
\hline 13 & 508 & Serine & $\begin{array}{l}\text { Phosphorylation of the } \\
\text { hinged domain }\end{array}$ & $\begin{array}{l}\text { DNA-dependent } \\
\text { protein kinase }\end{array}$ & Effects the transcriptional activity & [43] \\
\hline 14 & 703 & Lysine & Sumoylation & Ubc9 (Е3-лигаза) & - & [24] \\
\hline
\end{tabular}

inhibition of proteasome degradation of proteins leads to the enhanced transcriptional activity in tissues which may be related to the impaired degradation and persistent activity of the transcription factors in the nucleus. Another mechanism of the participation of proteasome degradation in the regulation of the activity of the glucocorticoid receptors is the stimulating effect of various agents, estrogens, in particular, on the expression of the specific E3-ligase Mdm2, inducing the decrease in GR activity [28]. Therefore, the activity of the proteasome is a key element in the dynamic regulation of the activity of steroid hormones.

Genetic polymorphism of NR3C1 gene. The polymorphism of genes, participating in the implementation of the stress response, is likely to play the key role, determining the discrepancies between the stressresponsiveness and resistance in the human population [1]. According to the data of the National Institutes of Health (USA) there are currently 2,571 known polymorphisms of human $\mathrm{NR} 3 \mathrm{Cl}$ gene of the single nucleotide polymorphism type (SNP, Fig. 4); among these polymorphisms, the incidence degree of the minor allele for 167 and 127 of them is over $10 \%$ and $1 \%$, respectively. We have discovered 42 missence-mutations among all SNPs, inducing the substitution of some amino acids in the structure of different isoforms of GR receptors. In addition to SNP, there are scientific literature data on the familial mutation of $\mathrm{NR} 3 \mathrm{Cl}$ gene with the deletion of four nucleotides, related to the intron and exon sites and leading to the termination of the expression of the damaged gene [29].

Missence polymorphisms. There are data on 42 missence SNPs in each of four domains of the proteins (Table 5). This Table demonstrates that the highest clinical significance is attributed to the polymorphisms, related to the transactivational and ligand-binding domains. The main impairments of the receptor function for these polymorphisms are as follows:

1) retardation of the activated receptor traslocation into the nucleus (proven for rs104893912, rs121 909727 and rs 104893908);

2 ) decreased affinity to the hormone (proven for rs121909727, rs104893908) or co-activators (proven for rs104893912, rs121909727);

3 ) the receptor instability (proven for rs 104893908);

4) decrease in the transactivational activity (proven for rs104893912, rs121909727 and rs104893914; assumed for rs148967394).

Among the polymorphisms given in Table 5, rs121909726, rs56149945, rs104893909, rs104893910, rs104893911, rs104893912, 


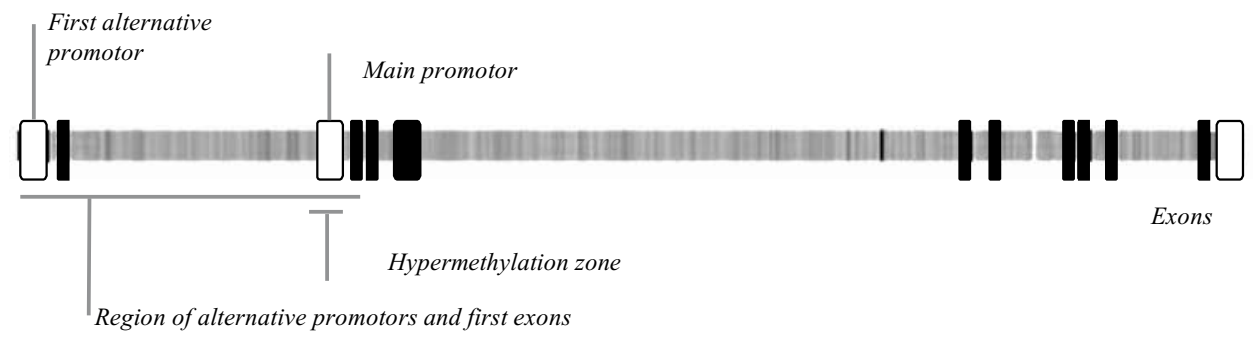

Fig. 4 Regional density of SNPs in various sites of $N R 3 C 1$ gene rs104893913, rs104893914, rs121909727 have been described in humans. All of them are the consequences of missence mutations, impairing the protein structure, and each of them induces the development of generalized familial forms of the glucocorticoid resistance. In case of rs 104893911 the resistance is accompanied by the hypokalemia and pseudohermaphroditism [30]. The main symptom of the glucocorticoid resistance is the high level of cortisone and ACTH in the blood plasma which may be related to the increase in the concentration of mineral-corticoid hormones and sex steroids [30].

The majority of the missence polymorphisms, studied in the human population, are remarkable for rather low frequency of incidence; there are rare homozygotes of mutant alleles, which may be explained by their inviability (see Table 5 ). In its turn, the low frequency of heterozygotes indicates a considerable effect of the negative natural selection regarding the mutations of $\mathrm{NR} 3 \mathrm{Cl}$ gene [31] which may be related to its significant role in the stress conditions and adaptation processes.

Polymorphisms of non-coding sites of the gene and other forms of non-missence mutations. The majority of SNPs in humans belong to intron sequences of the gene, which are adjoining the exons [31]. There are also some known mutations in the alternative exons, coding for the GR receptor isoform and the mutations, adding some more amino acids to the existing exons. The general description of these SNPs is presented in Table 6 .

Among all the polymorphisms, listed in Table 6, noteworthy are two polymorphisms of the highest clinical relevance: rs6198 and rs41423247.

The polymorphism rs6198 is the replacement of

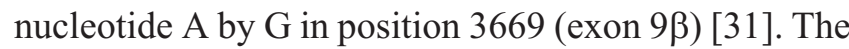
mutant variant leads to the change in the stability of variant GR- $\beta$ mRNA, and thus to its intensified synthesis. This GR isoform plays the role of dominant inhibitor of the active alpha-form of the receptor, inducing the reduced response to glucocorticoids. Therefore, the mutant form of the gene exhibits in a lower basal level of arterial pressure [31] as well as in an increased risk of rheumatoid arthritis and systemic lupus erythematosus [32] which might be explained by enhanced anti-inflammatory response, caused by the decreased sensitivity to glucocorticoids [31]. In addition, the formation of SNP by rs10482605 is facilitated by the haplotype, related to the increased risk of developing the major depression [5]. In total, the frequency of the mutant form in the Caucasian population of the USA is $19 \%$. SNP is remarkable for its dominant character which allows considering heterozygotes as a risk group for the described diseases.

Another widespread polymorphism rs41423247, also called $\mathrm{Bc} 1 \mathrm{I}$, is related to the replacement of $\mathrm{C}$ by $\mathrm{G}$ in position 41503, corresponding to the intron region of the gene [33]. It suggests the involvement of the mutation into the mechanisms of alternative splicing of mRNA and the changed products of receptor isoforms. The incidence degree for the minor allele is $26.4 \%$ which defines this polymorphism as one of the most widespread variants of $\mathrm{NR} 3 \mathrm{Cl}$ gene in the human population. SNP causes enhanced sensitivity to glucocorticoid hormones [33]. Many studies revealed that the carriers of Bc1I have increased risk of recurrent miscarriage [34], bronchial asthma [35], juvenile idiopathic arthritis [36] which may be caused by the decreased level of corticosterone, observed due to the enhanced sensitivity of GR receptors and the activated negative feedback loop of the regulation of HPA activity [37].

Other forms of polymorphisms with clinical description. Among all the known polymorphisms of $N R 3 C 1$ gene a special place is reserved to the mutations, revealed either very rarely or in families and remarkable for their vivid clinical picture. These 
Table5

Missens SNPS

\begin{tabular}{c|c|c|c|c|c|c}
\hline dbSNP ID & Replacement & $\begin{array}{c}\text { Position in } \\
\text { GR- } \alpha \text { protein }\end{array}$ & $\begin{array}{c}\text { Protein } \\
\text { domain }\end{array}$ & $\begin{array}{c}\text { Frequencies } \\
\text { (wild/hetero/mutant) }\end{array}$ & Clinical state & Mechanism \\
\hline 1 & 2 & 3 & 4 & 5 & 7 \\
\hline rs61759024 & Pro $\rightarrow$ Ser & 9 & TAD & $99,9 / 0,1 / 0 ; N=4428$ & n/d & Close of Tre8 phosphorylation \\
site
\end{tabular}

rs6190

ER22/23EK

Arg $\rightarrow$ Lys $\quad 23$

TAD

$90,3 / 9,7 / 0 ; N=226$

(европ.)

$\begin{array}{llccc}\text { rs72481829 } & \text { Asp } \rightarrow \text { Asn } & 25 & \text { TAD } & 0,6 / 0 / 99,4 ; N=356 \\ \text { rs148102613 } & \text { Phe } \rightarrow \text { Leu } & 29 & \text { TAD } & 100 / 0 / 0 ; N=4550 \\ \text { rs143711342 } & \text { Tyr } \rightarrow \text { His } & 30 & \text { TAD } & 99,0 / 0,1 / 0 ; N=4550 \\ \text { rs148967394 } & \text { Ser } \rightarrow \text { Pro } & 44 & \text { TAD } & 100 / 0 / 0 ; N=4550\end{array}$

\begin{tabular}{|c|c|c|}
\hline rs79138720 & Val $\rightarrow$ Gly & 50 \\
\hline rs6192 & Phe $\rightarrow$ Val & 65 \\
\hline rs 145020010 & Met $\rightarrow$ Val & 98 \\
\hline rs 72542740 & Gly $\rightarrow$ Arg & 99 \\
\hline rs72481830 & Asn $\rightarrow$ Ser & 130 \\
\hline rs 141093427 & Phe $\rightarrow$ Leu & 156 \\
\hline rs186831584 & $\mathrm{Val} \rightarrow \mathrm{Ile}$ & 163 \\
\hline rs 146524172 & Asn $\rightarrow$ Ser & 180 \\
\hline rs140309412 & Asn $\rightarrow$ Ile & 222 \\
\hline rs 72542742 & Ala $\rightarrow$ Thr & 229 \\
\hline rs 183372229 & Leu $\rightarrow$ Phe & 286 \\
\hline rs 72542743 & Ile $\rightarrow$ Val & 292 \\
\hline rs 72542745 & Ser $\rightarrow$ Gly & 325 \\
\hline rs72558022 & Asp $\rightarrow$ His & 346 \\
\hline rs 148470701 & Gln $\rightarrow$ Glu & 347 \\
\hline rs6195N363S & $\mathrm{Asn} \rightarrow \mathrm{Ser}$ & 363 \\
\hline rs56149945 & $\begin{array}{c}\text { Asn } \rightarrow \text { Ser } \\
\text { Asn } \rightarrow \text { Ile }\end{array}$ & 363 \\
\hline rs 1800445 & Asn $\rightarrow$ Ser & 365 \\
\hline
\end{tabular}

Non-clinical source

$99,2 / 0,8 / 0 ; N=4450$

AD $\quad 100 / 0 / 0 ; N=4222$

AD $\quad 99,8 / 0,2 / 0 ; N=526$

AD

$99,4 / 0,6 ; N=360$

$100 / 0 / 0 ; N=4548$

n/o

$100 / 0 / 0 ; N=4550$

$100 / 0 / 0 ; N=4224$

$99,7 / 0,3 / 0 ; N=4132$

$\mathrm{n} / \mathrm{o}$

Alleles: 99,8/0,2; $N=526$

Alleles: 99,8/0,2;

$$
N=526
$$

$\mathrm{n} / \mathrm{o}$

$95,8 / 4,2 / 0 ; N=48$

$95,9 / 4,0 / 0 / 0 ; N=$

$$
4550
$$

$\mathrm{n} / \mathrm{o}$
$94,4 / 5,6 / 0 ; N=18$
Associated with glucocorticoid resistance at Kron's disease [44]; one work demonstrates the association of cortisone products at social stress [45], while another one does not [46]

$\begin{array}{ll}\mathrm{n} / \mathrm{d} & \mathrm{n} / \mathrm{d} \\ \mathrm{n} / \mathrm{d} & \mathrm{n} / \mathrm{d} \\ \mathrm{n} / \mathrm{d} & \mathrm{n} / \mathrm{d}\end{array}$

Adjoins Ser45 phosphorylation site, which may result in the decrease in transactivational ability of receptors

$\mathrm{n} / \mathrm{d}$

$\mathrm{n} / \mathrm{d}$

No effect of the basal level of arterial pressure [31]

$\begin{array}{ll}\mathrm{n} / \mathrm{d} & \mathrm{n} / \mathrm{d} \\ \mathrm{n} / \mathrm{d} & \mathrm{n} / \mathrm{d} \\ \mathrm{n} / \mathrm{d} & \mathrm{n} / \mathrm{d} \\ \mathrm{n} / \mathrm{d} & \mathrm{n} / \mathrm{d} \\ \mathrm{n} / \mathrm{d} & \mathrm{n} / \mathrm{d} \\ \mathrm{n} / \mathrm{d} & \mathrm{n} / \mathrm{d} \\ \mathrm{n} / \mathrm{d} & \mathrm{n} / \mathrm{d} \\ \mathrm{n} / \mathrm{d} & \mathrm{n} / \mathrm{d} \\ & \mathrm{n} / \mathrm{d}\end{array}$

Close to Lys419 sumoylation site

$\mathrm{n} / \mathrm{d}$

$\mathrm{n} / \mathrm{d}$

$\mathrm{n} / \mathrm{d}$

$\mathrm{n} / \mathrm{d}$

$\mathrm{n} / \mathrm{d}$

$\mathrm{n} / \mathrm{d}$

Known clinical case

$\mathrm{n} / \mathrm{d}$

$\mathrm{n} / \mathrm{d}$ 
Окончание табл. 5

\begin{tabular}{|c|c|c|c|c|c|c|}
\hline 1 & 2 & 3 & 4 & 5 & 6 & 7 \\
\hline rs 147136661 & Ser $\rightarrow$ Phe & 370 & TAD & $100 / 0 / 0 ; N=4544$ & $\mathrm{n} / \mathrm{d}$ & $\mathrm{n} / \mathrm{d}$ \\
\hline rs 145046100 & $\mathrm{Thr} \rightarrow$ Ala & 413 & TAD & $\mathrm{n} / \mathrm{o}$ & $\mathrm{n} / \mathrm{d}$ & $\mathrm{n} / \mathrm{d}$ \\
\hline rs113048309 & Ser $\rightarrow$ Pro & 425 & DBD & $\mathrm{n} / \mathrm{o}$ & $\mathrm{n} / \mathrm{d}$ & $\mathrm{n} / \mathrm{d}$ \\
\hline rs 104893913 & Arg $\rightarrow$ His & 477 & DBD & $\mathrm{n} / \mathrm{o}$ & $\mathrm{n} / \mathrm{d}$ & $\mathrm{n} / \mathrm{d}$ \\
\hline rs 72542747 & Thr $\rightarrow$ Ser & 504 & HD & $\mathrm{n} / \mathrm{o}$ & $\mathrm{n} / \mathrm{d}$ & $\mathrm{n} / \mathrm{d}$ \\
\hline rs 72481843 & Gly $\rightarrow$ Ala & 516 & HD & Single case & $\mathrm{n} / \mathrm{d}$ & $\mathrm{n} / \mathrm{d}$ \\
\hline rs 33391 & Asn $\rightarrow$ Lys & 517 & HD & $\begin{array}{l}\text { Eight cases, not } \\
\text { observed in the } \\
\text { population }\end{array}$ & & \\
\hline rs 104893911 & $\mathrm{Val} \rightarrow \mathrm{Ala}$ & 571 & LBD & $?$ & \multicolumn{2}{|c|}{ Possible pathogenecity } \\
\hline rs 104893909 & Ile $\rightarrow$ Asn & 559 & LBD & Single case & $\mathrm{n} / \mathrm{d}$ & $\mathrm{n} / \mathrm{d}$ \\
\hline rs104893908 & $\mathrm{Asp} \rightarrow \mathrm{Val}$ & 641 & LBD & Single case & PGR & $\begin{array}{l}\text { Reduced affinity to the } \\
\text { hormone, impaired } \\
\text { transportation into the nucleus, } \\
\text { receptor instability [39] }\end{array}$ \\
\hline rs 113100205 & $\mathrm{Val} \rightarrow \mathrm{Ile}$ & 658 & LBD & Одна семья & $\mathrm{n} / \mathrm{d}$ & $\mathrm{n} / \mathrm{d}$ \\
\hline rs104893914 & Gly $\rightarrow$ Ser & 679 & LBD & $\mathrm{n} / \mathrm{o}$ & PGR & $\begin{array}{c}\text { Reduced transactivational effect } \\
{[47]}\end{array}$ \\
\hline rs68012717 & Asp $\rightarrow$ Glu & 687 & LBD & $\mathrm{n} / \mathrm{o}$ & & \\
\hline rs 121909727 & Phe $\rightarrow$ Leu & 737 & LBD & Single case & TGR & $\begin{array}{l}\text { Reduced affinity to the } \\
\text { hormone, delay in nuclear } \\
\text { translocation and impaired } \\
\text { interaction with NCOA2 } \\
\text { (GR-interacting protein-1 } \\
\text { co-activator) [48] }\end{array}$ \\
\hline rs 104893910 & Ile $\rightarrow$ Met & 747 & LBD & $?$ & & \\
\hline rs 121909726 & Leu $\rightarrow$ Phe & 753 & LBD & $\mathrm{n} / \mathrm{o}$ & & \\
\hline rs 186936077 & Asn $\rightarrow$ Asp & 766 & LBD & $\mathrm{n} / \mathrm{o}$ & & \\
\hline rs104893912 & Leu $\rightarrow$ Pro & 773 & LBD & Single case & TGR & $\begin{array}{l}\text { Two-fold reduction in } \\
\text { transactivational ability, } \\
\text { dominant-negative effect on } \\
\text { wild type of the receptor, } \\
\text { slowed-down translocation into } \\
\text { the nucleus, impaired } \\
\text { interaction with NCOA2 [49] }\end{array}$ \\
\hline
\end{tabular}

Note. DBD - DNA-binding domain; LBD - ligand-binding domain; TAD - transactivational domain; HD - hinged domain; PGR and TGR - primary and total glucocorticoid resistance; $\mathrm{n} / \mathrm{o}$ - no observation; $\mathrm{n} / \mathrm{d}$ - no data.

mutations promote deeper understanding of the functional relevance of the receptor and the mechanisms of controlling its activity. Below is a short description of two mutations, described in scientific literature. 
Table 6

The main clinically significant SNP in noncoding regions of the NR3Clgene

\begin{tabular}{|c|c|c|c|c|}
\hline dbSNP ID & TypeSNP & Minor allele frequency & Mutation region & clinical significance \\
\hline rs7701443 & $\mathrm{A} / \mathrm{G}$ & $\mathrm{G}: 46,8 \% ; N=1022$ & Intron & $\begin{array}{l}\text { Resistance to corticosteroids in children with Crohn's disease } \\
\qquad[44]\end{array}$ \\
\hline rs9324924 & $\mathrm{G} / \mathrm{T}$ & $\mathrm{T}: 44,8 \% ; N=978$ & Intron & $\begin{array}{l}\text { Data on the relationship with glucocorticoid resistance have not } \\
\text { been identified [50] }\end{array}$ \\
\hline rs4912911 & $\mathrm{A} / \mathrm{G}$ & $\mathrm{G}: 44,8 \% ; N=1000$ & Intron & Recessive resistance to corticosteroids [44] \\
\hline rs4607376 & $\mathrm{A} / \mathrm{G}$ & G: $43,8 \% ; N=957$ & Intron & $\begin{array}{l}\text { Data on the relationship with glucocorticoid resistance have not } \\
\text { been identified [50] }\end{array}$ \\
\hline rs6191 & $\mathrm{G} / \mathrm{T}$ & $\mathrm{G}: 42,3 \% ; N=923$ & $\begin{array}{l}\text { Exon } 9 \beta / 3 \text { '-flanking } \\
\text { region }\end{array}$ & $\begin{array}{l}\text { Possible relation with lithium resistance in patients with bipolar } \\
\text { disorder [51] due to depression [51] }\end{array}$ \\
\hline rs33388 & $\mathrm{A} / \mathrm{T}$ & $\mathrm{A}: 41,6 \% ; N=908$ & Intron & $\begin{array}{l}\text { Possible relation with lithium resistance in patients with bipolar } \\
\text { disorder [51] due to depression [51], there is no association with } \\
\text { rheumatoid arthritis [51] is not shown due to depression in } \\
\text { women in pre-menopausal women [52] }\end{array}$ \\
\hline rs6198 & $\mathrm{A} / \mathrm{G}$ & $\mathrm{G}: 9,2 \% ; N=201$ & $\begin{array}{l}\text { Exon } 9 \beta / 3 \text { '-flanking } \\
\text { region }\end{array}$ & See description in text \\
\hline rs41423247 & $\mathrm{C} / \mathrm{G}$ & $\mathrm{C}: 27,7 \% ; N=604$ & Intron & See description in text \\
\hline rs6196 & $\mathrm{A} / \mathrm{G}$ & $\mathrm{G}: 13,8 \% ; N=302$ & $\begin{array}{l}\text { Additional Asn in } \\
\quad \text { exon } 5\end{array}$ & $\begin{array}{l}\text { Resistance to corticosteroids in children with Crohn's disease } \\
\text { [44], communication with overweight [54], there is no } \\
\text { inter-connection with the response to psychosocial stress in } \\
\text { children, the association to high blood pressure [31] }\end{array}$ \\
\hline
\end{tabular}

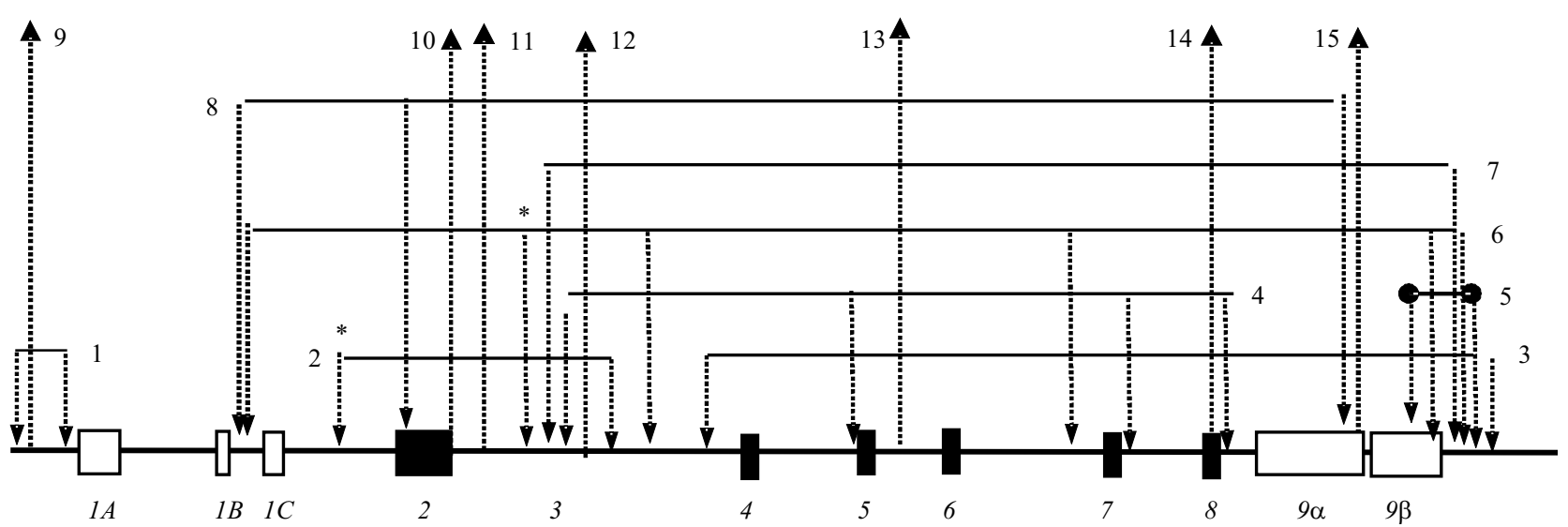

Fig. 5 The scheme of SNPs in the composition of the main haplotypes of NR3C1 gene (according to [31]). Detailed description of SNP and haplotypes is presented in Table 7.

In 1976 the authors of [38] described a medical case, when a patient had a high level of cortisone and ACTH associated with hypertension and hypokalemia with no other deviations. The proband's DNA demonstrated the mutation of SNP type, consisting in the substitution of valine for asparagine in position 641 of
GR- $\alpha$, corresponding to the hormone-binding domain (rs104893908) [39]. The mutation induced the decrease in the affinity to cortisone, the impaired transportation of the receptor into the nucleus and its total instability [39]. 
Noteworthy are three medical cases, revealed by the authors of [29] in one Danish family, caused by the deletion of four nucleotides in the donor splice site (here the pairs of nucleotides belonged to the sites of sixth intron and exon). The carriers of the clinical pathology were the father and three of five children; all these patients had evident hypercortisolism, caused by the functioning of only half of GR receptors. The proband was the daughter with hyperandrogenism, caused by the compensatory hyperproduction of the corticosteroid hormones [29].

Haplotypes of $\mathrm{NR} 3 \mathrm{Cl}$ gene in humans. The work [31] presents the detailed study of the NR3Cl gene haplotypes, consisting of various combinations of separate SNP, widespread among the main ethnic groups of American population. There were eight main revealed haplotypes, consisting of two and more SNP, which occur in the associations at the values of correlation coefficient 0.8 and over (Fig. 5, Table 7). In addition, the authors distinguished seven additional haplotypes, containing only one SNP, which are either rather frequent among Americans or of considerable relevance. It was established that haplotypes No. 2 and 3 are notable for their statistically reliable relation to the increased levels of the arterial pressure [31].

Unfortunately, at present we are unsuccessful in finding other studies on the NR3Cl gene haplotypes with sufficient representation.

Conclusions. Modern medical science is moving towards combining the results of genetic and molecular biological investigations with the clinical practice. The focus of the scientists tends to shift from the study on the monogenic diseases of low incidence level, but with a vivid and specific clinical picture, to the analysis of molecular mechanisms of polygenic, multifactorial diseases, which are widespread and remarkable for many clinical variants and types of the clinical course. In this regard there is a special interest to the glucocorticoid hormone receptors, which are one of the key regulators of immunological, stress and adaptation processes. The study on the relation of molecular biology and genetics of the GR receptors to the development of various forms of clinical pathological states and diseases offers new opportunities for further research in the sphere of pathophysiology and therapy of the diseases of civilization.

\section{Table 7}

Description of the main gene NR3C1 haplotypes, in the African Americans, Mexican and European Americans population ([31])

\begin{tabular}{c|cc}
\hline haplotype & SNP ID & SNP region \\
\hline 1 & -1225 & Distal promoter \\
& rs6868190 & Distal promoter \\
2 & rs10482616 & Intron 1C \\
& rs10482672 & Intron 3 \\
3 & rs852978 & Intron 3
\end{tabular}

\begin{tabular}{|c|c|c|}
\hline & rs6196 & Exon $9 \alpha$ (additional Asn) \\
\hline & rs 258748 & 3'-flanking region \\
\hline \multirow[t]{4}{*}{4} & rs852979 & Intron 3 \\
\hline & rs6188 & Intron 4 \\
\hline & rs 258813 & Intron 7 \\
\hline & rs 258750 & Intron 8 \\
\hline \multirow[t]{2}{*}{5} & rs6191 & Exon 9 $3 / 3^{\prime}$-flanking region \\
\hline & rs 258747 & 3'-flanking region \\
\hline \multirow[t]{6}{*}{6} & rs 10482605 & Proximal promoter \\
\hline & rs10482605 & Intron 2 \\
\hline & rs 123324 & Intron 3 \\
\hline & rs10482689 & Intron 6 \\
\hline & rs6198 & $\begin{array}{l}\text { Exon } 9 \beta / 3 \text { '-flanking regions } \\
\text { (AUUUA-sequence) }\end{array}$ \\
\hline & rs17287758 & 3'-flanking region \\
\hline \multirow[t]{2}{*}{7} & rs4986593 & Intron 2 \\
\hline & rs17209237 & Flanking region \\
\hline \multirow[t]{3}{*}{8} & rs 10482604 & Proximal promoter \\
\hline & rs6192 & Exon $2($ Phe $\rightarrow$ Val $)$ \\
\hline & rs10043662 & Exon $9 \alpha / 3^{\prime}$-flanking region \\
\hline 9 & -921 & Distal promoter \\
\hline 10 & rs6195 & Exon 2 (Asn $\rightarrow$ Ser) \\
\hline 11 & rs41423247 & Intron 2 (BclI) \\
\hline 12 & rs10482669 & Intron 3 \\
\hline 13 & rs10482682 & Intron 5 \\
\hline 14 & rs 258751 & Exon 8 (additional Asp) \\
\hline 15 & rs6193 & Exon $9 \alpha / 3$ '-flanking region \\
\hline
\end{tabular}




\section{М. А. Орловский}

Аллельный полиморфизм рецептора глюкокортикоидных гормонов NR3C1 (GR):

от молекулярной биологии к клинике

Институт физиологии им. А. А. Богомольца НАН Украины

Ул. Академика Богомольца, 4, Киев, Украина, 01024

Резюме

Полиморфизм генов, участвующих в реализации стрессорного ответа, является одним из ключевых фак- торов, определяюших различия в стресс-реактивности и резистентности в человеческой популяичи. Среди генов - регуляторов стресса в первую очередь следует выделить гены рецепторов глюкокортикоидов. В обзоре дана детальная характеристика их молекулярной биологии, на основании чего проведен анализ возможной связи наиболее распространенных вариантов SNP с альтерацией стрессорных реакичй и развитием клинической патологии.

Ключевые слова: глюкокортикоидные рецепторы, аллельный полиморфизм, SNP, NR3C1, GR, болезни адаптации.

М. О. Орловський

Алельний поліморфізм рецептора глюкокортикоїдних гормонів NR3C1 (GR): від молекулярної біології до клініки

Резюме

Поліморфізм генів, які беруть участь у реалізачії стресорної відповіді, є одним із ключових факторів, щзо визначають розбіжності в стрес-реактивності і резистентності в людській популяиії. Серед генів - регуляторів стресу у першу чергу варто відзначити гени рецепторів глюкокортикоїдів. В огляді надано детальну характеристику молекулярної біології даних генів, на підставі чого зроблено аналіз можливого зв 'язку найрозповсюдженіших варіантів SNP з альтерацією стресорних реакцій та розвитком клінічної патологї.

Ключові слова: глюкокортикоїдні рецептори, алельний поліморфізм, SNP, NR3C1, GR, захворювання адаптаціï.

\section{REFERENCES}

1. Bronnegard M., Stierna P., Marcus C. Glucocorticoid resistant syndromes - molecular basis and clinical presentations // J. Neuroendocrinol.-1996.-8, N 6.-P. 405-415.

2. Bray P. J., Cotton R. G. Variations of the human glucocorticoid receptor gene $(N R 3 C 1)$ : pathological and in vitro mutations and polymorphisms // Hum. Mutat.-2003.-21, N 6.-P. 557-568.

3. Cao-Lei L., Leija S. C., Kumsta R., Wust S., Meyer J., Turner J. D., Muller C. P. Transcriptional control of the human glucocorticoid receptor: identification and analysis of alternative promoter regions // Hum. Genet.2011.-129, N 5.-P. 533-543.

4. Turner J. D., Alt S. R., Cao L., Vernocchi S., Trifonova S., Battello N., Muller C. P. Transcriptional control of the glucocorticoid receptor: $\mathrm{CpG}$ islands, epigenetics and more // Biochem. Pharmacol.-2010.-80, N 12.-P. 1860-1868.

5. Kumsta R., Moser D., Streit F., Koper J. W., Meyer J., Wust $S$. Characterization of a glucocorticoid receptor gene $(G R, N R 3 C 1)$ promoter polymorphism reveals functionality and extends a haplotype with putative clinical relevance // Am. J. Med. Genet. B Neuropsychiatr. Genet.-2009.-150B, N 4.-P. 476-482.

6. Lu N. Z., Cidlowski J. A. Translational regulatory mechanisms generate $\mathrm{N}$-terminal glucocorticoid receptor isoforms with uni- que transcriptional target genes // Mol. Cell.-2005.-18, N 3.- P. 331-342.

7. Touriol C., Bornes S., Bonnal S., Audigier S., Prats H., Prats A. C., Vagner S. Generation of protein isoform diversity by alternative initiation of translation at non-AUG codons // Biol. Cell.- 2003.-95, N 3-4.-P. 169-178.

8. de Kloet E. R., Vreugdenhil E., Oitzl M. S., Joels M. Brain corticosteroid receptor balance in health and disease // Endocr. Rev.-1998.-19, N 3.-P. 269-301.

9. Oakley R. H., Sar M., Cidlowski J. A. The human glucocorticoid receptor beta isoform. Expression, biochemical properties, and putative function // J. Biol. Chem.-1996.-271, N 16.-P. 9550- 9559.

10. Strickland I., Kisich K., Hauk P. J., Vottero A., Chrousos G. P., Klemm D. J., Leung D. Y. High constitutive glucocorticoid recep-tor beta in human neutrophils enables them to reduce their spontaneous rate of cell death in response to corticosteroids // J. Exp. Med.-2001.-193, N 5.-P. 585-593.

11. Otto C., Reichardt H. M., Schutz G. Absence of glucocorticoid receptor-beta in mice // J. Biol. Chem.1997.-272, N 42.-P. 26665- 26668.

12. Rivers C., Levy A., Hancock J., Lightman S., Norman M. Insertion of an amino acid in the DNA-binding domain of the glucocorticoid receptor as a result of alternative splicing // J. Clin. Endocrinol. Metab.-1999.-84, N 11.-P. 4283-4286.

13. Ray D. W., Davis J. R., White A., Clark A. J. Glucocorticoid receptor structure and function in glucocorticoid-resistant small cell lung carcinoma cells // Cancer Res.-1996.-56, N 14.-P. 3276-3280.

14. Conway-Campbell B. L., McKenna M. A., Wiles C. C., Atkinson H. C., de Kloet E. R., Lightman S. L. Proteasome-dependent down-regulation of activated nuclear hippocampal glucocorticoid receptors determines dynamic responses to corticosterone // Endocrinology.2007.-148, N 11.-P. 5470-5477.

15. Meijer $O$. C. Coregulator proteins and corticosteroid action in the brain // J. Neuroendocrinol.-2002.-14, N 6.-P. 499-505.

16. Bledsoe R. K., Montana V. G., Stanley T. B., Delves C. J., Apo- lito C. J., McKee D. D., Consler T. G., Parks D. J., Stewart E. L., Willson T. M., Lambert M. H., Moore J. T., Pearce K. H., Xu H. E. Crystal structure of the glucocorticoid receptor ligand bin- ding domain reveals a novel mode of receptor dimerization and coactivator recognition // Cell.-2002.-110, N 1.-P. 93-105. 
17. Lightman S. L., Conway-Campbell B. L. The crucial role of pulsatile activity of the HPA axis for continuous dynamic equilibration // Nat. Rev. Neurosci.-2010.-11, N 10.-P. 710-718.

18. Meijer O. C., de Lange E. C., Breimer D. D., de Boer A. G., Workel J. O., de Kloet E. R. Penetration of dexamethasone into brain glucocorticoid targets is enhanced in $m d r 1 A$ P-glycoprotein knock-out mice // Endocrinology.1998.- 139, N 4.-P. 1789-1793.

19. Kitchener P., Di Blasi F., Borrelli E., Piazza P. V. Differences between brain structures in nuclear translocation and DNA bin- ding of the glucocorticoid receptor during stress and the circadian cycle // Eur. J. Neurosci.-2004.-19, N 7.-P. 1837-1846.

20. Bodwell J. E., Hu J. M., Orti E., Munck A. Hormone-induced hyperphosphorylation of specific phosphorylated sites in the mouse glucocorticoid receptor // J. Steroid Biochem. Mol. Biol.- 1995.-52, N 2.-P. 135-140.

21. Krstic M. D., Rogatsky I., Yamamoto K. R., Garabedian $M$. J. Mitogen-activated and cyclin-dependent protein kinases selectively and differentially modulate transcriptional enhancement by the glucocorticoid receptor // Mol. Cell. Biol.-1997.-17, N 7.- P. 3947-3954.

22. Wang Z., FrederickJ., Garabedian M. J. Deciphering the phosphorylation "code» of the glucocorticoid receptor in vivo // J. Biol. Chem.-2002.-277, N 29.-P. 26573-26580.

23. Itoh M., Adachi M., Yasui H., Takekawa M., Tanaka H., Imai $K$. Nuclear export of glucocorticoid receptor is enhanced by c-Jun N-terminal kinase-mediated phosphorylation // Mol. Endocri- nol.-2002.-16, N 10.-P. 2382-2392.

24. Tian S., Poukka H., Palvimo J. J., Janne O. A. Small ubiquitin- related modifier-1 (SUMO-1) modification of the glucocorticoid receptor // Biochem. J.-2002.-367, Pt 3.-P. 907-911.

25. Meijsing S. H., Pufall M. A., So A. Y., Bates D. L., Chen $L$., Ya-mamoto $K$. R. DNA binding site sequence directs glucocorticoid receptor structure and activity // Science.-2009.-324, N 5925.- P. 407-410.

26. Wang X., DeFranco D. B. Alternative effects of the ubiquitin- proteasome pathway on glucocorticoid receptor down-regulation and transactivation are mediated by CHIP, an E3 ligase // Mol. Endocrinol.-2005.-19, N 6.-P. 1474-1482.

27. Wallace A. D., Cidlowski J. A. Proteasome-mediated glucocorticoid receptor degradation restricts transcriptional signaling by glucocorticoids // J. Biol. Chem.- 2001.276, N 46.-P. 42714- 42721.

28. Kinуати H. K., Archer T. K. Estrogen receptordependent proteasomal degradation of the glucocorticoid receptor is coupled to an increase in mdm2 protein expression // Mol. Cell. Biol.-2003.-23, N 16.-P. 5867-5881.

29. Karl M., Lamberts S. W., Detera-Wadleigh S. D., Encio I. J., Stratakis C. A., Hurley D. M., Accili D., Chrousos G. $P$. Familial glucocorticoid resistance caused by a splice site deletion in the human glucocorticoid receptor gene //
J. Clin. Endocrinol. Me- tab.-1993.-76, N 3.-P. 683-689.

30. Mendonca B. B., Leite M. V., de Castro M., Kino T., Elias L. L., Bachega T. A., Arnhold I. J., Chrousos G. P., Latronico $A$. $C$. Fe- male pseudohermaphroditism caused by a novel homozygous missense mutation of the $G R$ gene // J. Clin. Endocrinol. Me- tab.-2002.-87, N 4.-P. 1805-1809.

31. Chung C. C., Shimmin L., Natarajan S., Hanis C. L., Boerwinkle E., Hixson J. E. Glucocorticoid receptor gene variant in the 3' untranslated region is associated with multiple measures of blood pressure // J. Clin. Endocrinol. Metab.-2009.-94, N 1.- P. 268-276.

32. DeRijk R. H., Schaaf M. J., Turner G., Datson N. A., Vreugden-hil E., Cidlowski J., de Kloet E. R., Emery P., Sternberg E. M., Detera-Wadleigh S. D. A human glucocorticoid receptor gene variant that increases the stability of the glucocorticoid receptor beta-isoform mRNA is associated with rheumatoid arthritis // J. Rheumatol.-2001.-28, N 11.-P. 2383-2388.

33. van Rossum E. F., van den Akker E. L. Glucocorticoid resistance // Endocr. Dev.-2011.-20.-P. 127-136.

34. Hanna C. W., Bretherick K. L., Liu C. C., Stephenson M. $D$., Robinson $W$. $P$. Genetic variation within the hypothalamus- pituitary-ovarian axis in women with recurrent miscarriage // Hum. Reprod.-2010.-25, N 10.-P. 2664-2671.

35. Pietras T., Panek M., Tworek D., Oszajca K., Wujcik R., Gorski P., Kuna P., Szemraj J.The BclI single nucleotide polymor- phism of the human glucocorticoid receptor gene $h-G R / N R 3 C 1$ promoter in patients with bronchial asthma: pilot study // Mol. Biol. Rep.-2011.-38, N 6.-P. 3953-3958.

36. Kostik M. M., Klyushina A. A., Moskalenko M. V., Scheplyagina L. A., Larionova V. I. Glucocorticoid receptor gene polymor- phism and juvenile idiopathic arthritis // Pediatr. Rheumatol. Online J.-2011.-9, N 1.-P. 2.

37. van Oosten M. J., Dolhain R. J., Koper J. W., van Rossum E. F., Emonts M., Han K. H., Wouters J. M., Hazes J. M., Lamberts $S$. $W$., Feelders $R$. A. Polymorphisms in the glucocorticoid receptor gene that modulate glucocorticoid sensitivity are associated with rheumatoid arthritis // Arthritis Res. Ther.-2010.-12, N 4.- R159.

38. Vingerhoeds A. C., Thijssen J. H., Schwarz F. Spontaneous hypercortisolism without Cushing's syndrome // J. Clin. Endocrinol. Metab.-1976.-43, N 5.-P. 1128-1133.

39. Hurley D. M., Accili D., Stratakis C. A., Karl M., Vamvakopoulos N., Rorer E., Constantine K., Taylor S. I., Chrousos G. P. Point mutation causing a single amino acid substitution in the hormone binding domain of the glucocorticoid receptor in familial glucocorticoid resistance// J. Clin. Invest.-1991.-87, N 2.-P. 680-686.

40. Krett N. L., Pillay S., Moalli P. A., Greipp P. R., Rosen S. $T$. A variant glucocorticoid receptor messenger RNA is expressed in multiple myeloma patients // Cancer Res.-1995.-55, N 13.- P. 2727-2729.

41. de Lange P., Segeren C. M., Koper J. W., Wiemer E., Sonneveld P., Brinkmann A. O., White A., Brogan I. J., de 
Jong F. H., Lam- berts S. W. Expression in hematological malignancies of a gluco- corticoid receptor splice variant that augments glucocorticoid receptor-mediated effects in transfected cells // Cancer Res.- 2001.-61, N 10.-P. 3937-3941.

42. Bodwell J. E., Orti E., Coull J. M., Pappin D. J., Smith L. I., Swift F. Identification of phosphorylated sites in the mouse glucocorticoid receptor // J. Biol. Chem.-1991.266, N 12.-P. 7549- 7555.

43. Giffin W., Kwast-Welfeld J., Rodda D. J., Prefontaine G. G., Traykova-Andonova M., Zhang Y., Weigel N. L., Lefebvre $Y$. A., Hache R. J. Sequence-specific DNA binding and transcription factor phosphorylation by $\mathrm{Ku}$ Autoantigen/DNA-dependent protein kinase. Phosphorylation of Ser-527 of the rat glucocorticoid receptor // J. Biol. Chem.-1997.-272, N 9.-P. 5647-5658.

44. Krupoves A., Mack D., Deslandres C., Seidman E., Amre $D$. $K$. Variation in the glucocorticoid receptor gene (NR3C1) may be associated with corticosteroid dependency and resistance in child- ren with Crohn's disease // Pharmacogenet. Genomics.-2011.-21, N 8.-P. 454-460.

45. van West D., Del-Favero J., Deboutte D., Van Broeckhoven $C$., Claes $S$. Associations between common arginine vasopressin $1 \mathrm{~b}$ receptor and glucocorticoid receptor gene variants and HPA axis responses to psychosocial stress in a child psychiatric population // Psychiatry Res.-2010.-179, N 1.-P. 64-68.

46. Bouma E. M., Riese H., Nolte I. M., Oosterom E., Verhulst F. C., Ormel J., Oldehinkel A. J. No associations between single nuc- leotide polymorphisms in corticoid receptor genes and heart rate and cortisol responses to a standardized social stress test in adolescents: the TRAILS study // Behav. Genet.-2011.-41, N 2.- P. 253-261.

47. Ruiz M., Lind U., Gafvels M., Eggertsen G., Carlstedt-Duke J., Nilsson L., Holtmann M., Stierna P., Wikstrom A. C., Werner $S$. Characterization of two novel mutations in the glucocorticoid re- ceptor gene in patients with primary cortisol resistance // Clin. Endocrinol. (Oxf.).-2001.-55, N 3.-P. 363-371.

48. Charmandari E., Kino T., Ichijo T., Jubiz W., Mejia L., Zachman K., Chrousos G. P. A novel point mutation in helix 11 of the ligand-binding domain of the human glucocorticoid receptor gene causing generalized glucocorticoid resistance // J. Clin. Endo-crinol. Metab.-2007.92, N 10.-P. 3986-3990.

49. Charmandari E., Raji A., Kino T., Ichijo T., Tiulpakov A., Zach- man K., Chrousos G. P. A novel point mutation in the ligand- binding domain (LBD) of the human glucocorticoid receptor (hGR) causing generalized glucocorticoid resistance: the impor- tance of the $\mathrm{C}$ terminus of hGR LBD in conferring transactiva- tional activity // J. Clin. Endocrinol. Metab.-2005.-90, N 6.P. 3696-3705.

50. Fingert J. H., Alward W. L., Wang K., Yorio T., Clark A. $F$. Assessment of SNPs associated with the human glucocorticoid receptor in primary open-angle glaucoma and steroid responders // Mol. Vis.-2010.-16.-P. 596-601.

51. Szczepankiewicz A., Leszczynska-Rodziewicz A., Pawlak J., Rajewska-Rager A., Dmitrzak-Weglarz M., Wilkosc M., Skibinska M., Hauser J. Glucocorticoid receptor polymorphism is associated with major depression and predominance of depression in the course of bipolar disorder // J. Affect. Disord.-2011.-134, N 1-3.- P. 138-144.

52. Chatzikyriakidou A., Georgiou I., Voulgari P. V., Georgiadis A. N., Argyriou E. S., Drosos A. A. Glucocorticoid receptor variants may predispose to rheumatoid arthritis susceptibility // Scand. J. Rheumatol.-2009.-38, N 1.-P. $1-5$.

53. Krishnamurthy P., Romagni P., Torvik S., Gold P. W., Charney D. S., Detera-Wadleigh S., Cizza G.; P. O. W. E. R. (Premeno- pausal, Osteoporosis Women, Alendronate, Depression) Study Group. Glucocorticoid receptor gene polymorphisms in preme-nopausal women with major depression // Horm. Metab. Res.- 2008.-40, N 3.-P. 194-198.

54. Moons T., Claes S., Martens G. J., Peuskens J., Van Loo K. M., Van Schijndel J. E., De Hert M., van Winkel R. Clock genes and body composition in patients with schizophrenia under treatment with antipsychotic drugs // Schizophr. Res.-2011.-125, N 2-3.-P. 187-193.

Received 09.07.12 